\title{
Primary ileoileal intussusception without a lead point simulating appendicular mass in a 4-year-old girl
}

\author{
Ramnik V Patel, ${ }^{1}$ Gregory Shepherd, ${ }^{2}$ Hemant Kumar, ${ }^{2}$ Bharat More ${ }^{2}$
}

Department of Surgery, PGICHR, Rajkot, Gujarat, India ${ }^{2}$ Department of Paediatric Surgery, LRI, Leicester, UK

\section{Correspondence to Dr Ramnik V Patel, ramnik@doctors.org.uk}

Accepted 18 February 2014

\section{DESCRIPTION}

A 4-year-old girl presented with a 4-day history of right-lower quadrant and suprapubic abdominal pain, vomiting and low-grade fever. On examination, she was found pale, tachycardic and with intermittent pain. Abdominal examination revealed a palpable tender but mobile mass in the suprapubic area. A clinical diagnosis of appendicular mass secondary to pelvic appendicitis was made. Urine dipstick and microscopy tests were normal. Full blood count was normal but $\mathrm{C}$ reactive protein was $30 \mathrm{mg} / \mathrm{L}$. As there was no clinicopathological correlation, an urgent abdominal ultrasound scan was performed. It showed an ileoileal intussusception with classic target/doughnut/bull's eye sign not amenable to air enema reduction (figure 1). She underwent exploratory laparotomy at which a primary ileoileal intussusception was found, which was very difficult to reduce, and had no lead point but a small segment of terminal ileum was non-viable and resection and primary end-to-end anatomosis was performed uneventfully. She was discharged home on third postoperative day and histology did not show any lead point. She presented again in 4 months' time with features of acute adhesive intestinal obstruction for which she underwent laparoscopy, adhesion lysis with segmental resection of terminal ileum with end-to-end ileoileostomy uneventfully. She is well and

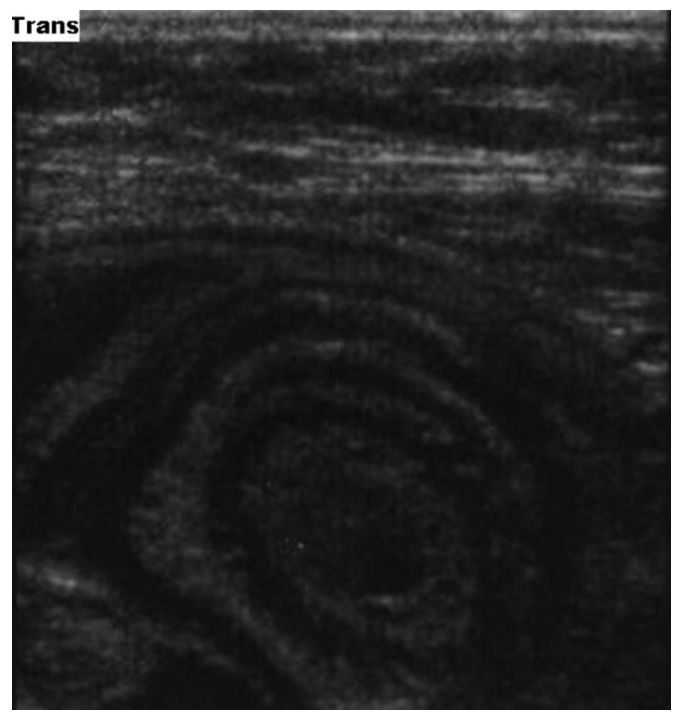

Figure 1 Abdominal ultrasound scan showing typical target/doughnut/bull's eye sign suggestive of an intussusception. asymptomatic at 2 years of follow-up. Primary ileoileal intussusception is rare at 4 years of age; it may simulate appendicular mass and an adult case has been reported, but none in children. ${ }^{1}$ An inflammatory pseudotumour may present with intussusception and a normal appendix may form a lead point of an intussuception. ${ }^{2}{ }^{3}$ Our case illustrates that barium enema reduction of intussusception is obsolete and in fact contraindicated ${ }^{4}$; there are still some cases in which an open traditional emergency surgery has some indications, although, at present, pneumatic air enema reduction is a gold standard, ultrasound-guided and laparoscopyguided reductions are gaining favour recently. ${ }^{5-8}$

\section{Learning points}

- Primary intussusception occurs in infancy with peak period between 5 and 9 months of age and is usually ileocolic while its occurrence at 4 years of age and ileoileal location is unusual. The reported sensitivity and specificity of ultrasound scan in the diagnosis of intussusception are almost $100 \%$.

- Ileoileal intussusceptions beyond 2 years of age usually have a lead point, the commonest being Meckel's diverticulum. Appendicular mass is treated conservatively, followed by interval or no appendicectomy in children, while an intussusception is a strangulating obstruction requiring urgent intervention.

- If a tender mass is palpable and the inflammatory markers (isolated rise in C reactive protein is an indicator of bowel vascular compromise and inflammation) are not in keeping with appendicular mass, lateral thinking and low threshold for urgent ultrasound to confirm or refute clinical diagnosis help, and air enema reduction is unfortunately not available for this entity and needs an operative intervention.

Contributors All the authors have made substantial contributions to the conception and design of the article, the search of literature, the acquisition, analysis and interpretation of the data, drafting the article or revising it critically for important intellectual content, and to the final approval of the version to be published.

Competing interests None.

Patient consent Obtained.

Provenance and peer review Not commissioned; externally peer reviewed. 


\section{REFERENCES}

1 Adelekan MO. Caeco-colic intussusception simulating an appendicular mass. Webmed Central Surg 2012;3:WMC003206.

2 Milne ANA, Sweeney KJ, O'Riodain DS, et al. Inflammatory myofibroblastic tumour with ALK/TPM3 fusion presenting as ileocolic intussusception: a usual presentation of an unusual neoplasm. Hum Pathol 2006:37:112-16.

3 Patton KR, Ferrera PC. Intussusception of a normal appendix. Am J Emerg Med 2000;18:115-17.

4 Tota-Maharaj R, Rampersad B, Indalsingh R. Barium enema reduction of intussusception in a developing country. West Indian Med $\mathrm{J}$ 2010;59:535-9.
5 Mensah YB, Glover-Addy H, Etwire V, et al. Pneumatic reduction of intussusception in children at Korle Bu Teaching Hospital: an initial experience. Afr J Paediatr Surg 2011;8:176-81.

6 Mensah Y, Glover-Addy H, Etwire V, et al. Ultrasound guided hydrostatic reduction of intussusception in children at Korle Bu Teaching Hospital: an initial experience. Ghana Med J 2011:45:128-31.

7 Almaramhy HH. Laparoscopic reduction of intussusception in children: role in primary and revisional reduction after failed non-surgical therapies. Int J Health Sci (Qassim); 2011;5:71-8.

8 Koplewitz BZ, Simanovsky N, Lebensart PD, et al. Air encircling the intussusceptum on air enema for intussusception reduction: an indication for surgery? Br J Radiol; 2011;84:719-26.

Copyright 2014 BMJ Publishing Group. All rights reserved. For permission to reuse any of this content visit http://group.bmj.com/group/rights-licensing/permissions.

BMJ Case Report Fellows may re-use this article for personal use and teaching without any further permission.

Become a Fellow of BMJ Case Reports today and you can:

- Submit as many cases as you like

- Enjoy fast sympathetic peer review and rapid publication of accepted articles

- Access all the published articles

- Re-use any of the published material for personal use and teaching without further permission

For information on Institutional Fellowships contact consortiasales@bmjgroup.com

Visit casereports.bmj.com for more articles like this and to become a Fellow 